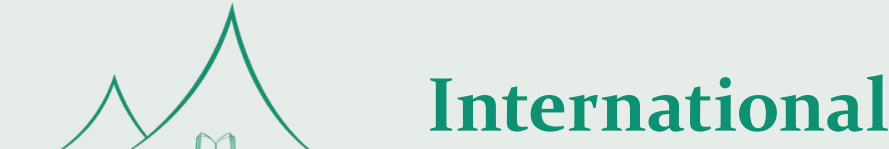 \\ madridge Journal of Physics: Study and Research \\ Interconnecting Scientific World
}

Research Article

Open Access

\section{Level of Electromagnetic Radiation Emitted from Mobile Phone Base Station during Fi Race in the Kingdom of Bahrain}

\author{
Hassan Alnajjar', Naser W Alnaser ${ }^{2}$, and Waheeb E Alnaser ${ }^{3 *}$ \\ ${ }^{1}$ Department of Physics, College of Science, University of Bahrain, Kingdom of Bahrain \\ ${ }^{2}$ Department of Architecture and Interior Design, College of Engineering, University of Bahrain, Kingdom of Bahrain
}

\section{Article Info}

\author{
*Corresponding author: \\ Waheeb E Alnaser \\ Professor \\ Department of Physics \\ College of Science \\ University of Bahrain \\ Bahrain \\ E-mail: walnaser@uob.edu.bh
}

Received: August 20, 2019

Accepted: August 28, 2019

Published: September 4, 2019

Citation: Alnajjar $\mathrm{H}$, Alnaser NW, Alnaser WE. Level of Electromagnetic Radiation Emitted from Mobile Phone Base Station during F1 Race in the Kingdom of Bahrain. Int J Phys Stud Res. 2019; 2(1): 65-70.

doi: 10.18689/ijpsr-1000109

Copyright: (c) 2019 The Author(s). This work is licensed under a Creative Commons Attribution 4.0 International License, which permits unrestricted use, distribution, and reproduction in any medium, provided the original work is properly cited.

Published by Madridge Publishers

\begin{abstract}
Measuring the power density of the Electromagnetic Radiation (EMR), or Radio frequency radiation, emitted from the mobile base station (transmitting mast) during three days event of Formula 1 Race in 4th, 5th and 6th April 2008 at Bahrain International Circuit, Kingdom of Bahrain, revealed that the exposure to EMR is much lower than the allowable limit set by several professional organization (seven organizations); it represents less than $0.1 \%$. The instantaneous recorded power density at distances 160 $\mathrm{m}, 230 \mathrm{~m}$ and $300 \mathrm{~m}$ from the transmitting mast were, on average, $46.5 \mu \mathrm{W} / \mathrm{m}^{2}, 86.8$ $\mu \mathrm{W} / \mathrm{m}^{2}, 395.8 \mu \mathrm{W} / \mathrm{m}^{2}$, respectively. The highest recorded instantons power density during the whole event was $901 \mu \mathrm{W} / \mathrm{m}^{2}$ and was on Sunday afternoon of $6^{\text {th }}$ April 2008, where it was the winner announcing day.

The long- term recorded power density during this international event shows lots of variation during this 90 minutes recording in last day (Sunday) of the event which is winner announcement event. This indicates that $\mathrm{F} 1$ spectators do substantial number of phone calls during the events where the variation in this day was from $0.607 \mu \mathrm{W} / \mathrm{m}^{2}$ to $16.832 \mu \mathrm{W} / \mathrm{m}^{2}$ while in Saturday was from $0.313 \mu \mathrm{W} / \mathrm{m}^{2}$ to $5.455 \mu \mathrm{W} / \mathrm{m}^{2}$ and in Friday was from $0.139 \mu \mathrm{W} / \mathrm{m}^{2}$ to $2.356 \mu \mathrm{W} / \mathrm{m}^{2}$.
\end{abstract}

Keywords: Electromagnetic Radiation (EMR); Radio frequency radiation; Power density; Formula 1; Bahrain International Circuit.

\section{Introduction}

The Bahrain International Circuit (BIC) is a motorsport venue opened in 2004 and used for the annual Bahrain Grand Prix (Formula 1 race). The 2004 Grand Prix was the first held in the Middle East. The construction of the Bahrain circuit was a national objective for Bahrain, initiated by the Crown Prince (H R H Shaikh Salman bin Hamad Al Khalifa) who is the Honorary President of the Bahrain Motor Federation. In 2007 the circuit became the first Grand Prix circuit to be awarded the distinguished FIA Institute Centre of Excellence award, given for excellent safety, race marshal, and medical facilities, and for the high standards of technology required to maintain these [1]. The circuit was designed by German architect. The main contractor for the project was a Bahraini company (Cebarco-WCT). The circuit cost was approximately BD 56.2 million (US\$150 million) to construct. $\mathrm{BIC}$ has six separate tracks, including a test oval and a drag strip. More information on Architectural and Environmental Aspects of the circuit can be found elsewhere [2,3].

About 28,000 spectators watched the race and the top year for Bahrain's Grand Prix was in 2008, when the race attracted 30,000 fans [4]. During the Formula 1 lots of Fans 
used their mobile phone heavily, and accordingly, the power density from the mobile phone base station (transmission mast) is expected to increase substantially. The concern about the Electromagnetic Radiation (EMR) emitted from transmitting mast becomes widely spread with lots of either exaggeration or under estimation. Therefore, lots of research were conducted to measure the levels of the radiation emitted from such transmitting mast either in schools, heavy population areas but no one had made measurement on such level in an international popular competition like FI Race.

Wood [5] reviewed the strength of the available epidemiological and laboratory evidence of the effect of EMR and notes that it falls short of what is normally required to establish a causal link. He reported low levels of power density which is up to a few thousandths of the permitted levels. However, it raises the importance of continuous and wholebody nature of the exposure of such radiation remembering that mobile phone transmissions are only part of the spectrum of EMF transmissions, along with radio, TV, and other communications networks.

Exposure to radiofrequency (RF) radiation was classified in 2011 as a possible human carcinogen, Group 2B, by the International Agency for Research on Cancer of the World Health Organization [6] although the RF radiation ( or EMR) is a non-ionizing radiation but has sufficient intensity to slightly heats tissues. Hardell et al. [6] made a total of 74,531 measurements corresponding to nearly $83 \mathrm{~h}$ of recording. The total mean RF radiation level was found equal to 3,811 $\mu \mathrm{W} / \mathrm{m}^{2}$ (ranging from 15.2 to $112,318 \mu \mathrm{W} / \mathrm{m}^{2}$ ) for the measurement of the whole apartment, including balconies. The closest base stations were only $6 \mathrm{~m}$ from the balcony outside the tower. Surprisingly, they concluded that the apartment is not suitable for long-term living because of this level of radiation, particularly for children who may be more sensitive than adults.

Meo et al. [7] had reported that high exposure to RF-EMF produced by mobile phone base station towers (MPBSTs) was associated with delayed fine and gross motor skills, spatial working memory, and attention in school adolescents compared to students who were exposed to low RF-EMF. Their study [7] is to investigate the impact of exposure to radiofrequency electromagnetic field (RF-EMF) radiation generated by MPBSTs on cognitive functions. They used 217 volunteer male students (aged between 13 and 16) registered from two different intermediate schools: 124 students were from School 1 and 93 students were from School 2. The MPBSTs were located within $200 \mathrm{~m}$ from the school buildings. They found that that the RF-EMF in School 1 was $2.010 \mu \mathrm{W} /$ $\mathrm{cm}^{2}\left(20.1 \mathrm{~mW} / \mathrm{m}^{2}\right)$ with a frequency of $925 \mathrm{MHz}$ and in School 2 was $10.021 \mu \mathrm{W} / \mathrm{cm}^{2}(100.2 \mathrm{~mW} / \mathrm{m} 2)$ with a frequency of 925 $\mathrm{MHz}$. The students were exposed to EMFR for 6 hrs a day, 5 days a week for a total period of 2 years.

Buckus et al. [8] presented and analyzed EMFs generated by mobile telephone base station antennas in areas accessible to the general public. Measurements of the RF electric field strength and RF EMF power density were conducted in the near- and far-fields of the mobile telephone base station antenna. Their tests, which were performed on the roof in front of the mobile telephony base station antennas in the near-field, revealed the presence of a dynamic energy interaction within the antenna electric field which changes rapidly with distance. The RF EMF power density values on the ground at distances of 50,100,200,300,400, and $500 \mathrm{~m}$ from the base station are very low and are scattered within intervals of 0.02 to $0.50 \mathrm{~mW} / \mathrm{m}^{2}$. The results were compared with international exposure guidelines (ICNIRP).

Chiaramello et al. [9] presented an overview of the last ten years research efforts about RF EMF exposure in indoor environments, considering different RF-EMF sources found to cause exposure in indoor environments, different indoor environments and different approaches used to assess the exposure. They reported that the highest maximum mean levels of the exposure, considering the whole RF-EMF frequency band, was found in offices $(1.14 \mathrm{~V} / \mathrm{m})$ and in public transports $(0.97 \mathrm{~V} / \mathrm{m})$, while the lowest levels of exposure were observed in homes and apartments, with mean values in the range $0.13-0.43 \mathrm{~V} / \mathrm{m}$ [9]. In their study they converted power density to Electric field strength $(\mathrm{V} / \mathrm{m})$ by:

$\mathrm{E}(\mathrm{V} / \mathrm{m})=\left(\mathrm{Z}_{0} \times \text { Power density }\right)^{1 / 2},\left(\mathrm{~W} / \mathrm{m}^{2}\right)$

where $Z_{0^{\prime}}$ equal to 377 and $\Omega$ is the impedance of vacuum.

Gallastegi et al. [10] studied RF-EMF exposure in the Spanish children by spot and personal measurements in the locations in order to identify which locations and sources contribute most to the level of exposure. 104 children (of age 8 years) were involved: spot measurements were conducted in homes, schools and their play grounds and parks. Results showed that median exposure levels ranged from $29.73 \mu \mathrm{W} /$ $\mathrm{m}^{2}(0.11 \mathrm{~V} / \mathrm{m}, 0.38 \%$ of the ICNIRP reference level) in children's bedrooms to $200.10 \mu \mathrm{W} / \mathrm{m}^{2}(0.27 \mathrm{~V} / \mathrm{m}, 0.88 \%$ of the ICNIRP reference level) in school playgrounds for spot measurements and were higher outdoors than indoors. The sources that contributed most to the exposure were FM radio, mobile phone downlink and Digital Video Broadcasting-Terrestrial, while indoor and personal sources contributed very little.

Due to rapid use of mobile phones (hence transmitting masts) public concern about the harmful effects of radiation emitted by these devices had grown. Therefore, ShahbaziGahrouei et al. [11] had used stem cells to assess the effects of radiofrequency electromagnetic fields (RF-EMF) on other cell lines. The effects of GSM $900 \mathrm{MHz}$ on growth and proliferation of mesenchymal stem cells, derived from adipose tissue, within the specific distance $(20 \mathrm{~cm})$ and intensity $(354.6$ $\mu \mathrm{W} / \mathrm{cm}^{2}$ ) with 5 times exposure was studied. They concluded that $900 \mathrm{MHz}$ RF signal radiation from antenna can reduce cell viability and proliferation rates of human Adipose-derived stem cells (ADSCs) regarding the duration of exposure [11].

In fact, this study is a unique since it measures level of EMR radiation from mobile base station (transmitting mast) during the three-days international event (Formula one Race) in $2008\left(4^{\text {th }}, 5^{\text {th }}, 6^{\text {th }}\right.$ April 2008) at the kingdom of Bahrain with an attendance of about 28,000 fans in the last day of the event. 


\section{Methodology}

The $\mathrm{RF}$ radiation measurements emitted from the mobile phone base stations at Bahrain International Circuit in AIZallaq area, kingdom of Bahrain (South of Bahrain and about $2 \mathrm{~km}$ from University of Bahrain) were recorded using a portable spectrum analyser connected to antenna. The spectrum analyzer model is SPECTRAN ${ }^{\circledR}$ HF- 6080 which is the best model among various models of $\mathrm{HF}$ detectors made by Aaronia AG, Germany (Figure 1). Some of the most important specifications of the devices are:

- Frequency range: $1 \mathrm{MHz}$ to $7 \mathrm{GHz}$

- Level range: $-90 \mathrm{dBm}$ to $30 \mathrm{dBm}$

- Power flux density range: $10 \mathrm{fW} / \mathrm{m}^{2}$ to $100 \mathrm{~W} / \mathrm{m}^{2}$ (where $\mathrm{fW}=10^{-15} \mathrm{~W}$ )

- Filter bandwidth range: $10 \mathrm{KHz}$ to $50 \mathrm{MHz}$

- Precision base unit $+/-3 \mathrm{dBm}$

The antenna connected to the spectrum analyser, HyperLOG ${ }^{\circledR} 6080$, is a logarithmic-periodic antenna and it is a single broadband antenna for the complete frequency range from $680 \mathrm{MHz}$ to $18 \mathrm{GHz}$. The antenna is calibrated precisely in the Aaronia laboratories before dispatch. Its gain is $5 \mathrm{dBi}$ and it has integrated $5 / 8^{\prime \prime}$ tripod socket and its dimensions is $(340 \times 200 \times 25) \mathrm{mm}$.

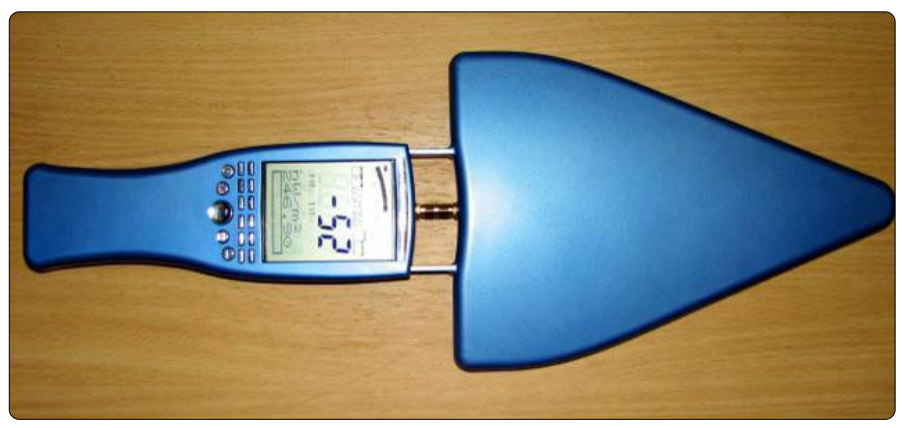

Figure 1. The spectrum analyzer connected with the antenna via SMA adapter.

Other equipment used in this research is tripod, adopter and five meters extension cable for long term (24 hours) measurements.

Three softwares were used in this study. First, the software used in processing and analyzing data is the Microsoft ${ }^{\circledR}$ office excel 2003 program. The second software is "Google Earth" which was used to specify the locations of the base stations and to determine the distance between each base station and the point of measurement. The third software used is SPECTRAN spectrum analyzer software "LCS" which was used in downloading the data saved in the spectrum analyzer during the long term measurements.

We had performed two types of measurements for the level of radiation emitting from the mobile base station. First is Instantons at different distances from the transmitting mast $(160 \mathrm{~m}, 230 \mathrm{~m}$ and $300 \mathrm{~m}$ ) (as shown in figure 2) and the second is relatively long-term (90 $\mathrm{min}$ ) at $310 \mathrm{~m}$ from the transmitting mast (as shown in figure 3). The measurements were made in every day of the 3-days international event at different time - according to the race schedule.

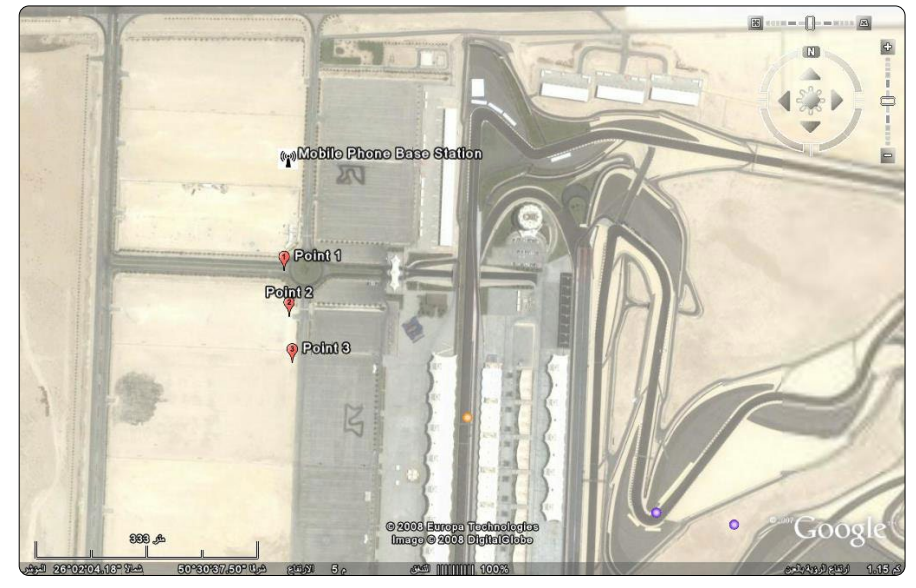

Figure 2. An aerial photo showing the locations of the points of measurement $(160 \mathrm{~m}, 230 \mathrm{~m}$ and $300 \mathrm{~m})$ of the level of EMR from the mobile base station at BIC, Kingdom of Bahrain.

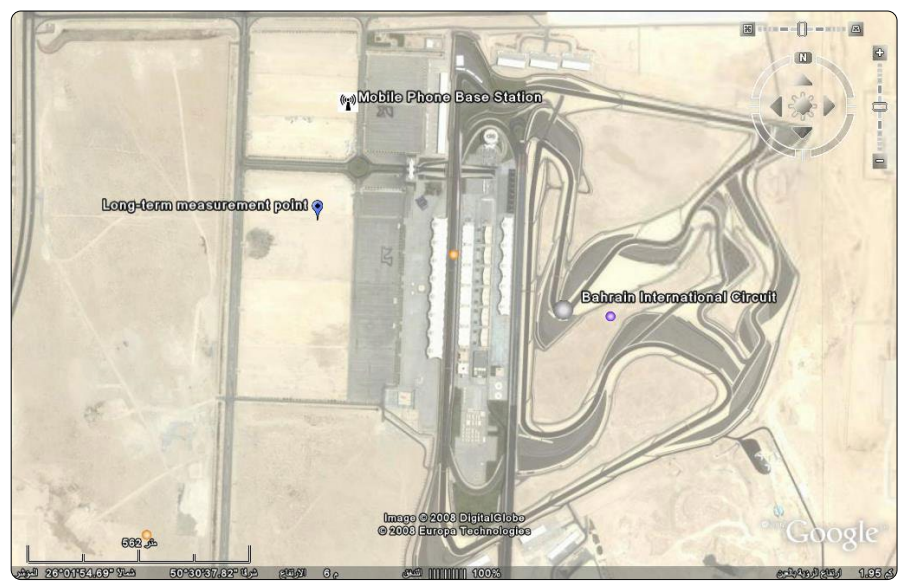

Figure 3. An aerial photo showing the locations of the point of measurement of the level of EMR from the mobile base station (310 $\mathrm{m})$ at BIC, Kingdom of Bahrain.

For the long-term power density measurement the device saves the data in $\mathrm{dBm}$ unit. To convert this unit $(\mathrm{dBm})$ to $\mu \mathrm{W} /$ $\mathrm{m}^{2}$ the following equation is used in accordance to the manual provided by the manufacturer of the detector (AARONIA AG, Germany):

$\mathrm{S}\left(\mathrm{W} / \mathrm{m}^{2}\right)=10^{[\mathrm{P}(\mathrm{dBm})-G(\mathrm{dBi})]} /{ }^{1000] \times(4 \pi / \lambda 2)]}, \ldots$

where $P$ is the measurement in $\mathrm{dBm}, \mathrm{G}$ is the Antenna gain $(G=5.0 \mathrm{dBi}$ for the used detector), $\lambda$ is the wavelength of the wave $\left(\lambda=3.0 \times 10^{8}(\mathrm{~m} / \mathrm{s}) / 9.5 \times 10^{8}(\mathrm{~Hz})\right)$. For example, for -40 $\mathrm{dBm}$ at $950 \mathrm{MHz}$ with Hyper LOG 6080 antenna (which offers a gain of $5.0 \mathrm{dBm}$ at $950 \mathrm{MHz}$ ) the equivalent power density in $\mathrm{W} / \mathrm{m}^{2}$ is 0.000002135 which is equal to $2.135 \mu \mathrm{W} / \mathrm{m}^{2}$.

The long-term power density measurement provides an idea on the variation of RF during a day. Moreover, it shows the maximum and minimum and therefore how much time lapse between them. This help in knowing also how the result in type one of measurements (environmental measurements) changes when the measurement conducted on another time of the day.

\section{Results and Discussion}

The events of Formula 1 Race in 2008 were in three days starting on Frid.ay $4^{\text {th }}$ April and ending on Sunday $6^{\text {th }}$ April. Each day two events are made; one in the morning and the 
other in the afternoon. Tables 1 to 4 shows the results of such measurements with substantially highest attendance from fans (about 28,000) on the final day ( $6^{\text {th }}$ April 2008) due to announcing the winner accompanied and followed by several entertainments. The other days has much less attendances from fans. This explains why the level of radiation $(901 \mu \mathrm{W} /$ $\mathrm{m}^{2}$ ) in the last day (Sunday at 2:00 pm) is about 20 times more than the average recorded level, excluding the level of EMR on Friday $4^{\text {th }}$ April $2008\left(456 \mu \mathrm{W} / \mathrm{m}^{2}\right)$ which is about half the level recorded in the final event.

Table 1. Measurement of the level of EMR from the transmitter mast (mobile base tower) on Friday morning of $4^{\text {th }}$ April 2008.

\begin{tabular}{|l|c|c|c|c|c|}
\hline & Time & Distance $(\mathrm{m})$ & Frequency $(\mathrm{MHz})$ & Power density $\left(\mu \mathrm{W} / \mathrm{m}^{2}\right)$ & Power $(\mathrm{dBm})$ \\
\hline Point 1 & $09: 46 \mathrm{am}$ & 160 & 954 & 71.20 & -33 \\
\hline Point 2 & $09: 50 \mathrm{am}$ & 230 & 950 & 91.56 & -31 \\
\hline Point 3 & $09: 52 \mathrm{am}$ & 300 & 949 & 112.44 & -30 \\
\hline
\end{tabular}

Table 2. Measurement of the level of EMR from the transmitter mast (mobile base tower) on Friday afternoon of $4^{\text {th }}$ April 2008.

\begin{tabular}{|l|c|c|c|c|c|}
\hline & & Distance $(\mathrm{m})$ & Frequency $(\mathrm{MHz})$ & Power density $\left(\mu \mathrm{W} / \mathrm{m}^{2}\right)$ & Power $(\mathrm{dBm})$ \\
\hline Point 1 & $4: 43 \mathrm{pm}$ & 160 & 948 & 31.35 & -36 \\
\hline Point 2 & $4: 46 \mathrm{pm}$ & 230 & 949 & 129.00 & -30 \\
\hline Point 3 & $4: 49 \mathrm{pm}$ & 300 & 941 & 455.74 & -24 \\
\hline
\end{tabular}

Table 3. Measurement of the level of EMR from the transmitter mast (mobile base tower) on Saturday afternoon of $5^{\text {th }}$ April 2008.

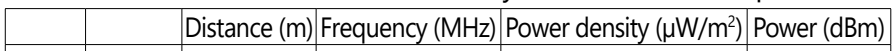

\begin{tabular}{|l|l|l|l|c|c|}
\hline Point 1 & $2: 43 \mathrm{pm}$ & 160 & 948 & 40.95 & -35 \\
\hline Point 2 & $2: 48 \mathrm{pm}$ & 230 & 948 & 27.84 & -37 \\
\hline Point 3 & $2: 50 \mathrm{pm}$ & 300 & 952 & 115.81 & -30 \\
\hline
\end{tabular}

Table 4. Measurement of the level of EMR from the transmitter mast ( mobile base tower) on Sunday afternoon of $6^{\text {th }}$ April 2008.

\begin{tabular}{|l|c|c|c|c|c|}
\hline & & Distance $(\mathrm{m})$ & Frequency $(\mathrm{MHz})$ & Power density $\left(\mu \mathrm{W} / \mathrm{m}^{2}\right)$ & Power $(\mathrm{dBm})$ \\
\hline Point 1 & $1: 54 \mathrm{pm}$ & 160 & 932 & 43.65 & -34 \\
\hline Point 2 & $1: 56 \mathrm{pm}$ & 230 & 942 & 98.80 & -31 \\
\hline Point 3 & $2: 01 \mathrm{pm}$ & 300 & 942 & 901.13 & -21 \\
\hline
\end{tabular}

For the long-term EMR emitting from the mobile base tower at a distance of $310 \mathrm{~m}$ from the detector we had conducted 4 sets of measurements each is lasting 90 minutes. The results are displayed in tables 5-8.

Table 5. The long-term EMR from the mobile base tower, at a distance of $310 \mathrm{~m}$ from the detector, on Friday $4^{\text {th }}$ April 2008 from 10:00 am to $11: 30 \mathrm{am}$.

\begin{tabular}{|c|c|c|c|}
\hline $\begin{array}{c}\text { Time } \\
\mathrm{am}\end{array}$ & Power Density $(\mathrm{dBm})$ & Power Density $\left(\mu \mathrm{W} / \mathrm{m}^{2}\right)$ & Frequency $(\mathrm{MHz})$ \\
\hline $10: 00$ & -42.41 & 1.092 & 949 \\
\hline $10: 05$ & -42.3 & 1.128 & 949 \\
\hline $10: 10$ & -44.34 & 0.554 & 953 \\
\hline $10: 15$ & -44.16 & 0.583 & 953 \\
\hline $10: 20$ & -44.07 & 0.599 & 953 \\
\hline $10: 25$ & -44.46 & 0.535 & 953 \\
\hline $10: 30$ & -44.24 & 0.553 & 954 \\
\hline $10: 35$ & -47.32 & 0.239 & 952 \\
\hline $10: 40$ & -47.12 & 0.254 & 952 \\
\hline $10: 45$ & -48.06 & 0.213 & 949 \\
\hline $10: 50$ & -48.58 & 0.183 & 949 \\
\hline $10: 55$ & -46.71 & 0.286 & 952 \\
\hline $11: 00$ & -48.21 & 0.185 & 952 \\
\hline $11: 05$ & -47.96 & 0.199 & 952 \\
\hline $11: 10$ & -47.26 & 0.244 & 952 \\
\hline $11: 15$ & -43.48 & 1.281 & 933 \\
\hline $11: 20$ & -47.51 & 0.227 & 952 \\
\hline $11: 25$ & -49.07 & 0.139 & 953 \\
\hline $11: 30$ & -39.85 & 2.356 & 948 \\
\hline
\end{tabular}

Table 6. The long-term EMR from the mobile base tower, at a distance of $310 \mathrm{~m}$ from the detector, on Friday $4^{\text {th }}$ April 2008 from 5:00 pm to $6: 20 \mathrm{pm}$.

\begin{tabular}{|c|c|c|c|}
\hline $\begin{array}{c}\text { Time } \\
\text { pm }\end{array}$ & Power Density $(\mathrm{dBm})$ & Power Density $\left(\mu \mathrm{W} / \mathrm{m}^{2}\right)$ & Frequency $(\mathrm{MHz})$ \\
\hline $5: 00$ & -43.13 & 0.788 & 953 \\
\hline $5: 05$ & -38.73 & 2.926 & 952 \\
\hline $5: 10$ & -38.3 & 3.229 & 953 \\
\hline $5: 15$ & -38.88 & 2.726 & 953 \\
\hline $5: 20$ & -38.04 & 3.484 & 953 \\
\hline $5: 25$ & -39.99 & 2.201 & 949 \\
\hline $5: 30$ & -39.9 & 2.080 & 952 \\
\hline $5: 35$ & -38.34 & 3.192 & 953 \\
\hline $5: 40$ & -36.97 & 5.013 & 951 \\
\hline $5: 45$ & -39.02 & 2.915 & 949 \\
\hline $5: 50$ & -37.97 & 3.651 & 952 \\
\hline $5: 55$ & -39.7 & 2.205 & 952 \\
\hline $6: 00$ & -39.83 & 2.066 & 953 \\
\hline $6: 05$ & -38.19 & 3.424 & 952 \\
\hline $6: 10$ & -38.65 & 2.916 & 953 \\
\hline $6: 15$ & -37.01 & 4.829 & 952 \\
\hline $6: 20$ & -37.9 & 3.726 & 952 \\
\hline
\end{tabular}

Table 7. The long-term EMR from the mobile base tower, at a distance of $310 \mathrm{~m}$ from the detector, on Saturday $5^{\text {th }}$ April 2008 from 3:00 pm to 4:20 pm.

\begin{tabular}{|c|c|c|c|}
\hline Time $\mathrm{pm}$ & Power Density $(\mathrm{dBm})$ & Power Density $\left(\mu \mathrm{W} / \mathrm{m}^{2}\right)$ & Frequency $(\mathrm{MHz})$ \\
\hline $3: 00$ & -42.17 & 1.013 & 954 \\
\hline $3: 05$ & -37.98 & 3.546 & 953 \\
\hline $3: 10$ & -41.96 & 1.244 & 949 \\
\hline $3: 15$ & -42.72 & 1.154 & 944 \\
\hline $3: 20$ & -45.32 & 0.548 & 944 \\
\hline $3: 25$ & -42.13 & 1.328 & 945 \\
\hline $3: 30$ & -37.57 & 5.455 & 941 \\
\hline $3: 35$ & -45.86 & 0.313 & 957 \\
\hline $3: 40$ & -45.05 & 0.592 & 944 \\
\hline $3: 45$ & -44.13 & 0.589 & 953 \\
\hline $3: 50$ & -43.46 & 0.737 & 952 \\
\hline $3: 55$ & -43.26 & 0.989 & 944 \\
\hline $4: 00$ & -41.75 & 1.249 & 951 \\
\hline $4: 05$ & -43.41 & 0.947 & 944 \\
\hline $4: 10$ & -41.64 & 1.253 & 952 \\
\hline $4: 15$ & -38.84 & 2.685 & 954 \\
\hline $4: 20$ & -40.83 & 1.632 & 951 \\
\hline
\end{tabular}

Table 8. The long-term EMR from the mobile base tower, at a distance of $310 \mathrm{~m}$ from the detector, on Sunday $6^{\text {th }}$ April 2008 from 4:00 pm to $5: 20 \mathrm{pm}$.

\begin{tabular}{|c|c|c|c|}
\hline $\begin{array}{c}\text { Time } \\
\mathrm{pm}\end{array}$ & Power Density $(\mathrm{dBm})$ & $\begin{array}{c}\text { Power Density } \\
\left(\mu \mathrm{W} / \mathrm{m}^{2}\right)\end{array}$ & Frequency $(\mathrm{MHz})$ \\
\hline $4: 00$ & -42.94 & 0.965 & 948 \\
\hline $4: 05$ & -34.62 & 12.334 & 942 \\
\hline $4: 10$ & -44.44 & 0.607 & 949 \\
\hline $4: 15$ & -33.53 & 16.832 & 942 \\
\hline $4: 20$ & -34.88 & 11.452 & 942 \\
\hline $4: 25$ & -37.02 & 6.219 & 942 \\
\hline $4: 30$ & -41.49 & 1.944 & 938 \\
\hline $4: 35$ & -35.22 & 10.393 & 942 \\
\hline $4: 40$ & -35.4 & 9.873 & 942 \\
\hline $4: 45$ & -40.36 & 2.033 & 948 \\
\hline $4: 50$ & -39.43 & 2.588 & 949 \\
\hline $4: 55$ & -37.32 & 4.768 & 949 \\
\hline $5: 00$ & -36.5 & 6.046 & 949 \\
\hline $5: 05$ & -34.2 & 11.767 & 949 \\
\hline $5: 10$ & -39.02 & 2.994 & 948 \\
\hline $5: 15$ & -37.21 & 4.797 & 950 \\
\hline $5: 20$ & -39.82 & 2.250 & 950 \\
\hline
\end{tabular}


The long-term results (Tables 6-9) shows that the variation in the recorded power density with time is more significant in Sunday than the other two days (Saturday and Friday) which indicates that spectators are using their phone while attending the last events of $F 1$ race very frequently. The variation in the time lapse $\left(90 \mathrm{~min}\right.$ ) in Friday is from $0.139 \mu \mathrm{W} / \mathrm{m}^{2}$ to 2.356 $\mu \mathrm{W} / \mathrm{m}^{2}$ in the morning session (Table 5) and from $0.788 \mu \mathrm{W} /$ $\mathrm{m}^{2}$ to $5.013 \mu \mathrm{W} / \mathrm{m}^{2}$ in the afternoon session (Table 6 ). In Saturday the variation was from $0.313 \mu \mathrm{W} / \mathrm{m}^{2}$ to $5.455 \mu \mathrm{W} / \mathrm{m}^{2}$ (Table 7) while in Sunday the variation was from $0.607 \mu \mathrm{W} / \mathrm{m}^{2}$ to $16.832 \mu \mathrm{W} / \mathrm{m}^{2}$ (Table 8).

The way the mobile phone network operates as follows [12]: When a call is made from a mobile phone, RF signals are transmitted between its antenna and the antenna at a nearby transmitting mast. The phone call is then routed through the phone network to the destination phone. Therefore, base station antennas must be elevated and located clear of physical obstruction to ensure wide coverage.

Therefore, in international or popular sport (like F1 race) or social events, where mobile phones are expected to be used very frequently, an additional number of base stations is needed to maintain service quality increases, even in areas where mobile network coverage already exists. Good service quality will reduce consumption of batteries of the mobile phone and prevent heating of the battery as power is drawn from battery to enable the phone to send the signal. In fact if this is not done the mobile network will not operate properly and, as a result, mobile phone users may not be able to connect to their network [12].
The Biolnitiative Report (2012) - updated 2014-2019 [13] defined the scientific benchmark for possible health risks as 30 to $60 \mu \mathrm{W} / \mathrm{m}^{2}$. Considering also chronic exposure and the sensitivity of children, the precautionary target level was proposed at $1 / 10$ th of this, i.e., $3-6 \mu \mathrm{W} / \mathrm{m}^{2}$ [13] but since this exposure target level has not been acknowledged by the Swedish Radiation Safety Authority (SSM) then it becomes questionable.

The exposimeter in World Health Organization (WHO) building in Geneva on 3 March 2017 recorded a low mean total exposure level of $21.5 \mu \mathrm{W} / \mathrm{m}^{2}$, median $13.3 \mu \mathrm{W} / \mathrm{m}^{2}$ (range $\min 4.8, \max 433 \mu \mathrm{W} / \mathrm{m}^{2}$ ) [14], i.e., a mean level below the scientific benchmark of 30 to $60 \mu \mathrm{W} / \mathrm{m}^{2}$ which has been proposed as the 'lowest observed effect level' (LOEL) for RF radiation [15]. In the Kingdom of Bahrain, the recommended exposure limit of power density is $0.1 \mathrm{~W} / \mathrm{m}^{2}\left(100,000 \mu \mathrm{W} / \mathrm{m}^{2}\right)$ which is set by the Pollution Control Section, Supreme Environmental Council.

Table 9 lists different reference levels for save general public exposure for frequency band of GSM 900 (925-960 $\mathrm{MHz}$ ) set by different professional and specialized organizations such as International Commission on Nonlonizing Radiation Protection (ICNIRP), National Radiological Protection Board (NRPB), Institute of Electrical and Electronics Engineers (IEEE), Federal Communications Commission (FCC), The Australian Radiation Protection and Nuclear Safety (ARPANS).

Table 9. Comparison between different save Reference Levels for general public exposure for frequency band of GSM 900 (925-960 MHz) [16].

\begin{tabular}{|l|c|c|c|c|}
\hline Organization & $\begin{array}{c}\text { E-field strength } \\
(\mathrm{V} / \mathrm{m})\end{array}$ & $\begin{array}{c}\text { H-field strength } \\
(\mathrm{A} / \mathrm{m})\end{array}$ & $\begin{array}{c}\text { Power density } \\
\left(\mathrm{W} / \mathrm{m}^{2}\right)\end{array}$ & $\begin{array}{c}\text { Power density } \\
\left(\mu \mathrm{W} / \mathrm{m}^{2}\right)\end{array}$ \\
\hline ICNIRP & $41.82-42.60$ & $0.113-0.115$ & $4.63-4.80$ & $4,630,000-4,800,000$ \\
\hline NRPB & $115.63-120.00$ & $0.305-0.317$ & $35.08-37.79$ & $3,508,000-3,779,000$ \\
\hline IEEE & ---- & ---- & $6.17-6.40$ & $617,000-640,000$ \\
\hline FCC & ---- & --- & $6.17-6.40$ & $617,000-640,000$ \\
\hline ARPANS & $41.67-42.45$ & $0.111-0.113$ & $4.63-4.80$ & $463000-480,000$ \\
\hline CANADA & $48.21-49.11$ & $0.128-0.130$ & $6.17-6.40$ & $617,000-640,000$ \\
\hline ITALY & 6 & 0.016 & 0.1 & 100,000 \\
\hline
\end{tabular}

The save limits set in table 10 is too far larger than that set Bioinitiative Report 12. Considering the highest peak level measured within the WHO building $\left(432.3 \mu \mathrm{W} / \mathrm{m}^{2}\right)$ - measured at 15:54:07 in $3^{\text {rd }}$ March 2017, then the recorded radiation during F1 Race in April 2008 in Bahrain is considered to be very save in general, except in the last day. It has to be noted that most contribution of radiation in WHO building was from GSM 1800 (DL), $268.2 \mu \mathrm{W} / \mathrm{m}^{2}$, and UMTS 2100 (DL), 110.4 $\mu \mathrm{W} / \mathrm{m}^{2}$. This was measured just inside the building at the entrance and represent RF radiation from base stations in the vicinity [15].

Luckily, the occurrence of EMR changes rapidly with distance and they scattered in different directions toward the ground as this radiation carry non-ionizing radiations but have a heat effect known as biological effects on human health [6]. This means that the power density recorded during F1 Race in April, $4^{\text {th }}$ to $6^{\text {th }}, 2008$ in Bahrain was just about to be save. This means more mobile base stations must be installed to reduce the power density.

\section{Conclusion}

The power density emitted from the mobile base station (transmitting mast) during the three days event in April 2008 $\left(4^{\text {th }}, 5^{\text {th }}\right.$ and $\left.6^{\text {th }}\right)$ of $\mathrm{F} 1$ race (Formula 1$)$ at Bahrain International Circuit is much lower than that set by several professional organization (7 organizations); it represents less than $0.1 \%$ while if it is compared to that set by Bioinitiative Report 12 it is considered as within the satisfactory limit.

The instantaneous recorded power density at distances $160 \mathrm{~m}, 230 \mathrm{~m}$ and $300 \mathrm{~m}$ from the transmitting mast were, on average, $46.5 \mu \mathrm{W} / \mathrm{m}^{2}, 86.8 \mu \mathrm{W} / \mathrm{m}^{2}, 395.8 \mu \mathrm{W} / \mathrm{m}^{2}$, respectively. The highest recorded instantons power density during the whole event was $901 \mu \mathrm{W} / \mathrm{m}^{2}$ and was on Sunday afternoon of $6^{\text {th }}$ April 2008, where it was the winner announcing day.

The long-term recorded power density during this international event shows lots of variation during this 90 minutes recording in last day (Sunday) of the event which is winner announcement event. This indicates that F1 spectators 
do substantial number of phone calls during the events where the variation was from $0.607 \mu \mathrm{W} / \mathrm{m}^{2}$ to $16.832 \mu \mathrm{W} / \mathrm{m}^{2}$ while in Saturday was from $0.313 \mu \mathrm{W} / \mathrm{m}^{2}$ to $5.455 \mu \mathrm{W} / \mathrm{m}^{2}$ and in Friday was from $0.139 \mu \mathrm{W} / \mathrm{m}^{2}$ to $2.356 \mu \mathrm{W} / \mathrm{m}^{2}$. This leads to the suggestion of installing more transmitting masts for better quality signal and less power density transmitting.

\section{Acknowledgment}

The authors would like to thank University of Bahrain for providing all facilities to enable the researchers to conduct this study. Special thanks to Dr Lama Sakhniny, Department of Physics, College of Science for her technical assistance and discussions. Thanks to the administration of BIC to provide the facilities to conduct the measurements during the F1 race events.

\section{References}

1. Bahrain named Centre of Excellence by FIA. Formula1.com.

2. Alnaser WE, Flanagan R, El-Masri S, Al-Khalifa SE, Probert SD, Alnaser NW. Bahrain's Formula-1 Racing Circuit: Energy and Environmental Considerations. Applied Energy. 2006; 83(4): 352-370. doi: 10.1016/j.apenergy.2005.04.006

3. Alnaser NW, Flanagan R, Al-Khalifa SE, Mumtaz R, El-Masri S, Alnaser WE. Architectural, Construction and Environmental matters of Bahrain's International Formula1 Circuit. Building and Environment. 2007; 42(4): 1783-1794. 10.1016/j.buildenv.2006.01.014

4. Lifestyle. Bahrain F1 race watched by 28,000 fans.

5. Wood AW. How dangerous are mobile phones, transmission masts, and electricity pylons? Arch Dis Child. 2006; 91(4): 361-366. doi: 10.1136/ adc.2005.072561

6. Hardell L, Carlberg M, Hedendahl LK. Radiofrequency radiation from nearby base stations gives high levels in an apartment in Stockholm, Sweden: A case report. Oncol Lett. 2018; 15(5): 7871-7883. doi: 10.3892/ol.2018.8285
7. Meo SA, Almahmoud M, Alsultan Q, Alotaibi N, Alnajashi I, Hajjar WH Mobile Phone Base Station Tower Settings Adjacent to School Buildings: Impact on Students' Cognitive Health. Am J Mens Health. 2019; 13(1): 1-6. doi: $10.1177 / 1557988318816914$

8. Buckus R, Strukčinskienè B, Raistenskis J, et al. A Technical Approach to the Evaluation of Radiofrequency Radiation Emissions from Mobile Telephony Base Stations. Int J Environ Res Public Health. 2017; 14(3): 244254. doi: 10.3390/ijerph14030244

9. Chiaramello E, Bonato M, Fiocchi S, et al. Radio Frequency Electromagnetic Fields Exposure Assessment in Indoor Environments: A Review. Int $J$ Environ Res Public Health. 2019; 16: 955-984. doi: 10.3390/ijerph16060955

10. Gallastegi M, Huss A, Santa-Marina L, et al. Children's exposure assessment of radiofrequency fields: Comparison between spot and personal measurements. Environ Int. 2018; 118: 60-69. doi: 10.1016/j.envint.2018.05.028

11. Shahbazi-Gahrouei $D$, Hashemi-Beni B, Ahmadi Z. Effects of RF-EMF Exposure from GSM Mobile Phones on Proliferation Rate of Human Adipose-derived Stem Cells: An In-vitro Study. J Biomed Phys Eng. 2016; 6(4): 243-252.

12. Arpansa. Mobile phone base stations and health. Australian government.

13. Biolnitiative Report. The bioinitiative report 2012: A Rationale for Biologically-based Public Exposure Standards for Electromagnetic Fields (ELF and RF).

14. Sage C, Carpenter DO. Key Scientific Evidence and Public Health Policy Recommendations. In: Biolnitiative Working Group: Biolnitiative Report 2012: A Rationale for Biologically-based Public Exposure Standards for Electromagnetic Radiation.

15. Hardell L. World Health Organization, radiofrequency radiation and health-a hard nut to crack (Review). Int J Oncol. 2017; 51(2): 405-413. doi: 10.3892/ijo.2017.4046

16. Al-Najjar HA. Measurement and Analysis of Radiofrequency Radiation Levels from Mobile Phone Base Stations in the Kingdom of Bahrain. MSC Thesis, Master of Science Program in Environment and Sustainable Development, University of Bahrain, Kingdom of Bahrain. 2007. 